\title{
Problems and Thoughts of Issuing Municipal Bond to Fiscal Revenue
}

\author{
Jiawen Zhao, Qingjun Meng, Zhijian Wu \\ Department of Accounting, Business School, Hohai University, Nanjing, China \\ Email: 18168309839@163.com
}

How to cite this paper: Zhao, J. W., Meng, Q. J., \& Wu, Z. J. (2018). Problems and Thoughts of Issuing Municipal Bond to Fiscal Revenue. Chinese Studies, 7, 220-229. https://doi.org/10.4236/chnstd.2018.73019

Received: July 11, 2018

Accepted: August 6, 2018

Published: August 9, 2018

Copyright $(\odot) 2018$ by authors and Scientific Research Publishing Inc. This work is licensed under the Creative Commons Attribution International License (CC BY 4.0).

http://creativecommons.org/licenses/by/4.0/

\begin{abstract}
Since the declaration of new Budget Law makes issuing municipal bond possible, many local governments deem it as an important way to get fiscal revenue. There is no doubt that issuing municipal bond along with tax revenue, nontax revenue and transfer revenue has become a significant source of fiscal revenue. However, it also brings local government heavy financial burden, backward areas especially. Few new bonds were used to carry out regional construction. And the rest of them usually were issued for the paybacks of former loans. This paper is aimed to analyze the influence of issuing Municipal bond to fiscal revenue and the problems and get the conclusions.
\end{abstract}

\section{Keywords}

Municipal Bond, Fiscal Revenue, Insolvency Risk, Credit Risk

\section{Introduction}

The "Budget Law of the People's Republic of China" of 1994 stipulates that local governments shall not issue bonds except for special reasons. The "tax-sharing system reform" has broadened fiscal revenues for local governments, but local governments still have large funding gaps in infrastructure construction especially for the construction of major projects. In order to solve the urgent demand of local governments for funds, the Ministry of Finance has gradually relaxed its policies, allowing local governments to issue local bonds, and has continuously imposed legislative restrictions on this behavior (Jiang, 2010). This move provides local governments with a new legal financing platform that can increase fiscal revenue and ease the pressure on the fiscal deficit. However, due to the need to repay local bonds, local governments have also had a new source of financial pressure (Li, 2017).

This paper aims to analyze the impact on local fiscal revenue and the prob- 
lems in the issuance process by investigating the issuance of local government bonds in 2016 and 2017. On the one hand, the local government's debt repayment pressure is too large. On the other hand, although the "Budget Law" imposes many restrictions on local government borrowing, it still can't stop some local governments from having too much debt. When many local governments issued additional local bonds, a considerable portion of them were to replace stock debts and issue "new debts" to solve "old debts". In fact, there were not many new debts for development and construction. In addition, the local government credit rating lacks credibility, and the government's debt repayment pressure can be passed on to the rise of housing prices. In response to these problems, this paper proposes some countermeasures to improve the current situation, such as strengthening the supervision of local government bonds and accelerating the construction of new financing channels such as PPP.

The structure of this paper is as follows: Firstly, it analyzes the impact of issuing local bonds on local fiscal revenue, then points out the problems existing in the issuance of local bonds in China, and then puts forward suggestions and countermeasures for these problems, and finally summarizes the full text.

\section{The Impact of Issuing Local Bonds on Local Fiscal Revenue}

\subsection{Broaden the Source of Fiscal Revenue}

Since the reform of opening up, China's economic development has been on the fast track, and its economic construction has been effective. However, once the local government had "large powers and small financial power" it undertook many construction tasks, but there was a shortage of funds. The 1994 "Budget Law" stipulated that the failure to issue local government bonds stimulated the thirst for local governments (Cheng \& Wang, 2013). This hunger and thirst was eased after permitting the issuance of local bonds. Local governments replaced large amounts of other debt with local bonds and issued new debt to face the pressure of new funding. The increase in "debt income" has led many local governments' accounts to break even. Especially in recent years, on the one hand, the task of local government construction is heavy. On the other hand, the national economic growth has slowed down, and the growth rate of tax revenue has also slowed down accordingly. Local governments have increasing financial pressure, and issuance of local bonds has apparently filled this part of the funding gap and widened the sources of fiscal revenue.

\subsection{Standardize Debt Fiscal Revenue}

Because the previous regulations cannot issue government bonds, local governments will use a variety of other channels to carry out financing, such as bank project loans and trust private equity, in order to meet the needs of local fiscal revenues and expenditures. A wide range of debt income not only increases the difficulty of managing fiscal revenue, but also increases the risk of debt repay- 
ment, which easily leads to management loopholes. Therefore, when the new "Budget Law" allowed the issuance of local bonds, the debt income of local governments began to be dominated by local bonds, which not only eased management pressure, but also helped standardize local government debt financial revenue.

\subsection{Optimize the Structure of Government Debt Fiscal Revenue}

According to statistics, in the government's debt income at the end of 2012, the proportion of bank loans was as high as $78 \%$, and the issuance of bonds was only about $12 \%$. Excessive reliance on banks will cause banks' operating risks to be tied up with the government's debt repayment risks. Once the government loses its financing, or if the government's debt repayment risk is too high to be able to repay debts in time, the risks of both will be great (Zhang, 2016). The issuing of bonds by local governments can optimize the structure of local government debt fiscal revenues, spreading risks to a certain extent, and making the structure of local government debt income more reasonable.

\subsection{Make Government Financing Behavior More Open and Transparent}

A variety of ways of borrowing make it difficult for most people to fully understand the government's financing behavior. China is actively pushing local governments to prepare balance sheets. Although there are few government announcements at present, once it is announced, it will clearly show the situation of government bond financing. This allows the government to obtain financial revenue through financing more transparent and transparent, which is conducive to the supervision of higher levels of government, relevant departments, and the people.

\section{The Current Problems of Local Bonds in China}

\subsection{Some Local Governments Have Too Much Capital Demand, and the Debt Repayment Pressure Is Too Large}

Figure 1 and Figure 2 reflect proportion of local new bonds and replacement of old debts in 2016 and 2017. At present, many local bonds are issued to replace old debts. According to data from the Ministry of Finance of the State Council, the proportion of old debt replacement in 2016 was $81 \%$, and the proportion of old debt replacement in 2017 was $64 \%$. Although the proportion of replacement of old debt has declined over time, less than $50 \%$ of the bonds issued by local governments each year for local construction, that is, most of the government bonds are used to fill the previous debt gap. The emergence of the "bond-forcredit" situation will, on the one hand, causes local governments to face higher and higher financing costs, and this part of the financing costs will be generated from stock debt and will not be able to bring about any local construction, but will continue to pay interest on the old debts. On the other hand, when the bond concentration expires, it brings heavy debt repayment pressure to local govern- 
ments and continues to build up debt.

\subsection{Lack of Emergency Measures When Local Governments Are Unable to Pay Their Debts}

The "Budget Law" requires that local government bonds be "self-repay" and the central government does not help. But suppose that if the local government really fails to pay its debts, who will repay the principal and interest of these bonds? In the United States, some local governments declared bankruptcy because they were unable to pay off bonds due (Song, 2005), and in today's China, it is impossible to declare the bankruptcy of the government.

Table 1 and Table 2 show the balances and limits of local government bonds in various regions of China in 2016 and 2017. Figure 3 reflects the proportion of quotas used in each region. As can be seen from the chart, the total amount of use is above $70 \%$, and even more than $90 \%$ in the Midwest. The use of quotas in the eastern region is relatively small, and the quotas in the western regions are the most used. According to the financial final report of Inner Mongolia, the local government's special bond issuance in 2017 even exceeds the limit.

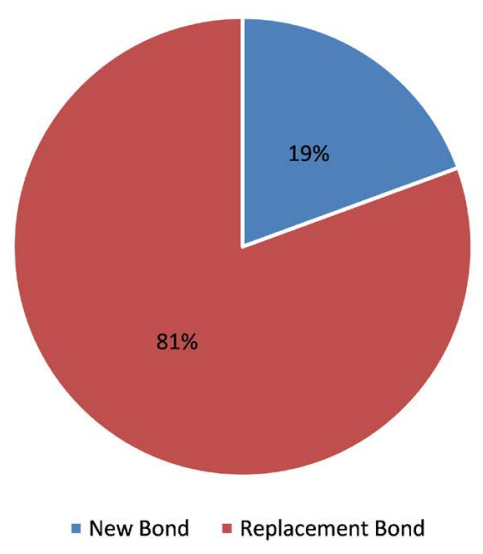

Figure 1. Proportion of local new bonds and replacement of old debts in 2016.

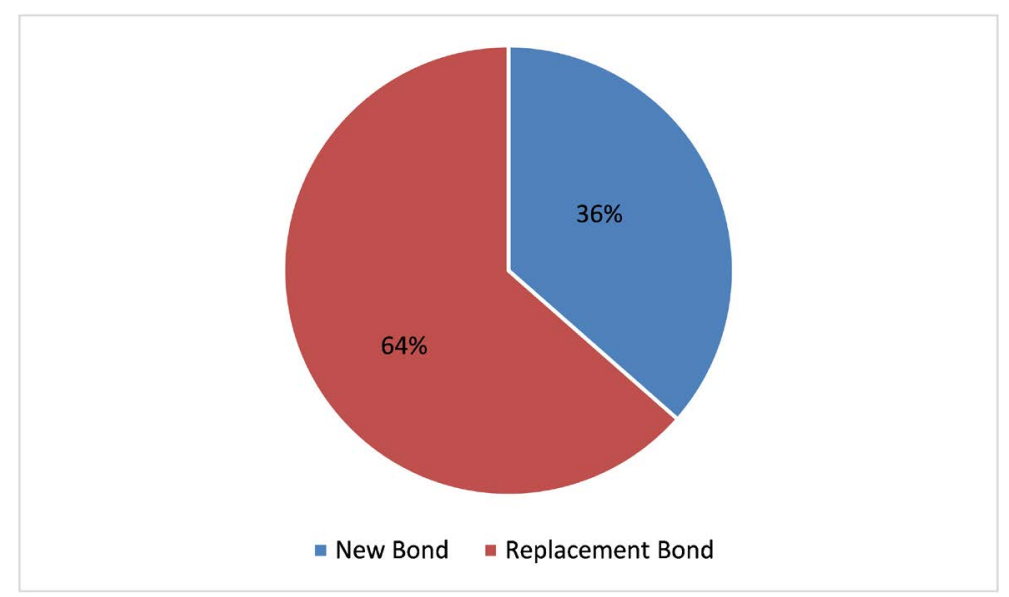

Figure 2. Proportion of local new bonds and replacement of old debts in 2017. 


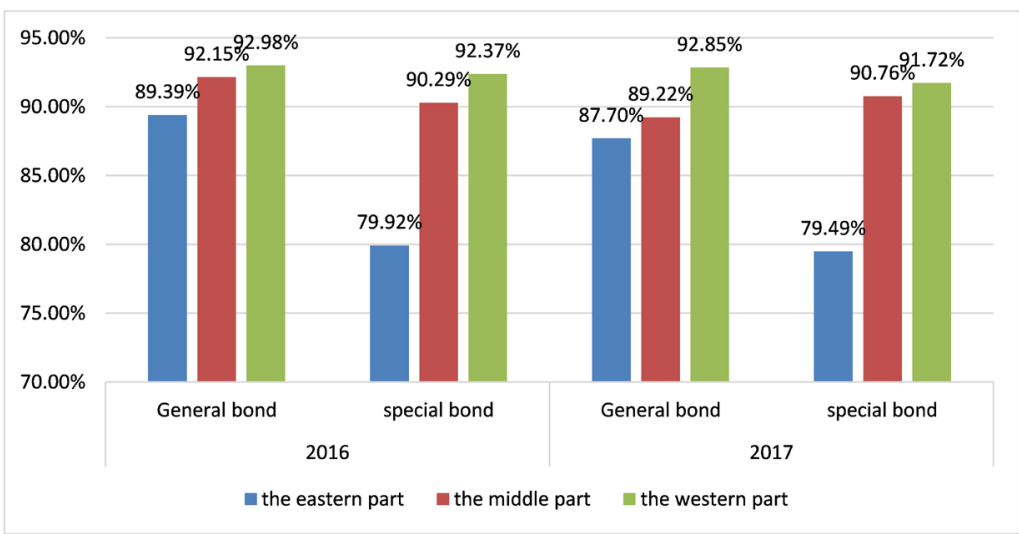

Figure 3. Use of local government bond quotas in different regions in 2016 and 2017.

Table 1. Balance of general and special bond in various regions of China in 2016 and 2017.

\begin{tabular}{ccccc}
\hline Year & \multicolumn{2}{c}{2016} & \multicolumn{2}{c}{2017} \\
\hline Types of Bonds & General bond & special bond & General bond & special bond \\
the eastern part & $41,648.57$ & $27,512.64$ & $43,240.10$ & $31,029.78$ \\
the middle part & $24,012.22$ & $11,027.49$ & $25,264.20$ & $13,056.17$ \\
the western part & $30,001.27$ & $15,225.90$ & $32,891.41$ & $15,752.84$
\end{tabular}

Table 2. Limit of general and special bond in various regions of China in 2016 and 2017.

\begin{tabular}{ccccc}
\hline Year & \multicolumn{2}{c}{2016} & \multicolumn{2}{c}{2017} \\
\hline Types of Bonds & General bond & special bond & General bond & special bond \\
the eastern part & $46,593.20$ & $34,424.60$ & $49,306.20$ & $39,035.60$ \\
the middle part & $26,057.13$ & $12,213.97$ & $28,316.13$ & $14,384.93$ \\
the western part & $32,266.29$ & $16,483.71$ & $35,425.29$ & $17,174.30$ \\
\hline
\end{tabular}

Therefore, there is currently a contradiction: Local governments do have certain debt repayment risks. In fact, the government cannot go bankrupt and the central government does not help. What if those local governments with higher risks are really unable to repay their debt? Is the debt extended, whether it continues to issue bonds to increase fiscal revenue or whether it has obtained assistance from the central government in disguised form?

\subsection{Local Government Credit Rating Lacks Credibility}

The Central Government requires local governments to conduct credit ratings before issuing bonds, but it is not difficult to find out that the results of local government credit ratings are basically AAA-level highest credit ratings. The result of being too perfect has been questioned by many scholars. The US local government credit rating shows the result of the Normal distribution. Is the Chinese government's perfect rating result really reliable and can be used as an effective basis for issuing local bonds? 
In fact, at present, China's local government credit rating system does need to be strengthened. First of all, the rating agencies have had experience mainly for companies rather than governments. Many of the indicators are applicable to companies and it is difficult for the government to say. In addition, local governments are often affected by pressure on fiscal revenues, which put pressure on rating agencies. From the results, rating agencies basically compromise on the government. Therefore, at present, China's rating agencies are far from meeting the requirements for rating local governments, both from a technical perspective and from an independent perspective.

\subsection{Bond Interest Rates Are Not Enough Incentives for Investors}

Local bonds should have been the product of the marketization of local fiscal revenue. The interest rate of bonds should also match the size of their risks. However, the interest rates of many local bonds are similar to those of national bonds and are even lower than those of national bonds. Obviously, local government bonds have become bonds with high risks and low returns, breaking the laws of the market. This is because commercial banks, which are the main buyers of government bonds, exchange interest with local governments in order to absorb a large number of financial deposits with low capital costs. As a result, once the interest swap is lost, the issuance of government bonds is likely to have problems. For example, Liaoning Province has experienced the embarrassment of failed to issue bonds (Xie, 2013).

\subsection{Local Government's Transfer of Debt Crisis May Raise Housing Prices}

Land financing is also an important way for local governments to increase their fiscal revenue. When the government is unable to repay bond principal and interest, the government can obtain legitimate fiscal revenue by transferring the land use rights of the jurisdiction (Zhang, 2013). According to the audit office data, the proportion of the nation's commitment to repay debt through land sales income is as high as $37 \%$, and in some provinces it is more than $50 \%$ (Dou, 2016). However, the land is limited. In order to obtain as much fiscal revenue as possible from limited land, local governments will continue to raise the prices of land use rights. Therefore, real estate developers often express their feelings that "it is hard to get it now" and "land is expensive". Similarly, real estate developers, after assuming high development costs, will inevitably pass on costs to home buyers for profits. In China's real estate market, most homebuyers choose to buy mortgage loans from banks. These debts then pass through the government, real estate developers, home buyers, and eventually return to the bank. The debtor changed from the local government to the residents. Although the debt risk still exists, the residents generally use the real estate as the collateral for the security. Therefore, the debt is distributed apportioned and finally resolved.

The only problem is that the rising housing prices not only bring huge pres- 
sure for residents to buy houses, but once bubbles appear and the houses are no longer worth the money, banks will have a lot of bad loans. The central government has been actively stabilizing housing prices. Under such circumstances, it is obviously not an effective means for local governments to repay debts through land financing to transfer debts to residents.

\section{Suggestions and Countermeasures}

From the foregoing, we can see that the issuance of local bonds is an important means for stabilizing fiscal revenues and developing local economies. However, some of the problems and negative effects brought about by local bonds can't be underestimated. In response to these problems, the paper proposes some suggestions and countermeasures.

\subsection{Adhere to the Policy of Issuing Local Bonds}

Although there are many problems with local bonds, it is undeniable that bond financing has greatly broadened the source of fiscal revenue for local governments and stabilized the development of local economies, especially in the light of the slowdown economic growth in recent years and the simultaneous slowdown in tax revenue. Under these circumstances, it also injected a lot of vitality into local fiscal revenue.

In addition, the issuance of local bonds can clarify the government's debt income, optimize the structure of this source of income, and reduce the risk of over-reliance on banks. Second, at this time, many bonds of local governments are "rolling" issues, and new debts are used to repay old debts. Therefore, if government bonds are to be suspended, local governments will suddenly face enormous pressure for debt repayment, and they will not be able to roll out indefinitely by "rolling" of issuance of bonds, which will increase the risk of debt repayment.

Therefore, no matter from which point of view, although there are problems that need to be solved, issuing local government bonds to increase fiscal revenue is a necessary measure.

\subsection{Strengthen Supervision over the Issuance and Circulation of Local Bonds}

The original intention of the issuance of local bonds is to strengthen local special projects. However, it is not known how much funds the local government will need in the end. Whether or not corruption will be followed by regional construction after financing is unknown.

Strengthening the supervision of the issuance and circulation of local debt requires a two-pronged approach. On the one hand, it is the control of risks. Just as a company publicly issues bonds, it needs to satisfy a series of conditions, how the solvency is, how the capital structure is, and how the operating capacity is. If the risk is too high, it will not be issued. The same is true of local governments. 
If it is not appropriate for the issuance of bonds to issue the government, it is not allowed to issue bonds. It uses legal means to force local governments to actively manage their financial revenues and expenditures, and it also reduces the risk of debt repayment.

On the other hand, it is to improve the local government rating system. At present, the credit rating ratings agencies have made to the Chinese government are almost always at the highest level. The degree of fairness is clearly questioned. Therefore, rating agencies and local governments should be completely independent and issue rating results fairly (Gu \& Qiu, 2014; Yue, 2016). At the same time, it is also necessary to improve the rating procedures and standards for local governments so as to differentiate them from the general corporate credit rating, and it is more applicable to government agencies.

\subsection{Accelerate the Construction of New Financing Models Such as PPP}

According to the new "Budget Law" stipulations, "the borrowed debt should have a repayment plan and a stable source of repayment funds, which can only be used for public welfare capital expenditures and not for recurring expenditures." On the one hand, it shows that government bonds cannot be used for recurring expenditure items. Otherwise, the debt gap may increase and the risk may be too great. On the other hand, it can be seen that major revenue such as tax revenue can actually meet the government's current expenditures. The issuance of bonds is mainly when local governments are faced with the construction of relatively large projects, which require debt financing, such as special bonds.

In terms of special projects, China already has new financing models such as PPP and BOT. If we can develop and use this model more quickly and better, we can not only attract private capital, broaden local government revenue channels, and reduce government funds. It can also activate private capital and give full play to the strength of social capital for regional development. At this stage, we need to further improve such a model and strengthen the attractiveness of this cooperation mechanism for private capital and strengthen the cooperation.

\subsection{Accelerate the Disclosure of Balance Sheets and Strengthen Supervision by All Sectors}

What the local government currently mainly discloses is the financial final cost document. Some provinces, such as Jiangsu Province, disclosed the issuance of local bonds in the final accounts, and wrote "According to the annual report of government debt, as of 2016, the provincial government's debt balance was 1091.535 billion yuan, of which: the general debt was 641.319 billion yuan. Debt was 450.013 billion yuan, and the provincial government's debt balance was 47.653 billion yuan, of which: the general debt was 47.613 billion yuan and the special debt was 40 million yuan. The province's debt ratio in 2016 was $62.9 \%$, and the local government debt risk was generally controllable." Government 
documents, in fact, can already see the key information. However, some governments, such as Gansu, are not able to see government-related information in the accounts documents. However, when they read the data, they can know that the Gansu government's debt repayment risk is relatively high, and the correlation among them is evident. Therefore, accelerating the promotion of the disclosure of the balance sheet is conducive to promoting the transparency and transparency of local government bonds and giving full play to the supervision role of all sectors of society.

\section{Conclusion}

According to the latest data, although China's current government bond issuance volume is relatively large, it is more reassuring than liabilities and assets. In spite of this, the government will not, in any case, wish to go to use the stateowned assets to offset the debt. Therefore, it is necessary to prevent local bond risks.

Local debt is like a double-edged sword. It can inject vitality into the local economy and bring debt repayment risk. The use of this weapon can optimize the government revenue structure, standardize the source of debt income, and promote the good development of the local government economy. Although domestic governments have not experienced the phenomenon of insolvency of local government funds, they still need to be cautious in issuance and management in order to draw lessons from the US government's case of bankruptcy due to the debt crisis.

In addition, innovative government financing channels continue to attract private capital, and governments and enterprises cooperate in project construction to achieve mutual benefits and win-win results. This is also a good solution to the current government funding problem.

\section{Conflicts of Interest}

The authors declare no conflicts of interest regarding the publication of this paper.

\section{References}

Cheng, F., \& Wang, H. C. (2013). Research on Local Government Debt under the Framework of Fiscal Decentralization. Journal of Socialist Theory Guide, 3, 83-85.

Dou, L. J. (2016). The Predicament and the Way out of the Local Government Bond Financing in China under the View of the Rule of Law. Economic Law Review, 1, 77-102.

Gu, Q. M., \& Qiu, Y. (2014). Research on Credit Risk Measurement of Local Government Bonds in China. Collected Essays on Finance and Economics, 7, 25-30.

Jiang, C. Q. (2010). A Historical Investigation of the Issuance of Local Bonds in China Three Times-From the Perspective of Changes in Fiscal System. Financial Theory \& Practice, 4, 20-33.

Li, H. X. (2017). Local Government Debt Risk and Prevention under the New Situation. Sub National Fiscal Research, 6, 82-88. 
Song, L. (2005). International Comparison and Enlightenment of Local Public Institutional Bond Financing System-Taking American Municipal Bonds and Japanese Local Bonds as Examples. Comparative Economic and Social Systems, 3, 76-83.

Xie, Q. (2013). Future Local Bond Issuance Model Proposal in China. Review of Economic Research, 42, 15-16.

Yue, B. (2016). Suggestions on the Improvement of China's Local Government Bond System. Financial Theory \& Practice, 4, 60-62.

Zhang, L. L. (2013). The Enlightenment of American and Japanese Local Debt Issuing Experiences to China. South China Finance, 5, 43-52.

Zhang, Y. R. (2016). Legal Thinking on Local Bonds Resolving Local Government Debt Structure Risk. Jianghuai Tribune, 1, 98-104. 